\title{
THE OPTIMIZATION OF CORRUPTION PREVENTION TOWARDS INDONESIA CORRUPTION-FREE ${ }^{\Omega}$
}

\author{
Hibnu Nugroho, Agus Raharjo, and Pranoto \\ Law Faculty of Jenderal Soedirman University \\ E-mail: hibnunugroho@gmail.com
}

\begin{abstract}
Prevention and eraducation of corruption case are the strategy which can't be implemented separatly it should be done synergistically, integrated and concurrently to prevent a new corruptor generation and other new corruptor. So the problem comes on how the strategy which are prevention and eraducation corruption by Indonesian goverment to reach Indonesia free from corruption and what the obsacles in order to reach strategy prevention and eraducation of corruption that already done by Indonesiaan goverment. This research used empirical yuridical method with descriptive analysis, qualitatieve descriptive and conten analysis. By this research can be known that goverment already had preventive and solutive corruption strategy to solve corruption, but there is still be found obstacles such as oerlaping, weak supervison among institution, profesion that related with law enforcemen and not maximal enough witness and informal protection.
\end{abstract}

Keyword : law enforcement, prevention of corruption, legal culture.

\begin{abstract}
Abstrak
Pencegahan tindak pidana korupsi merupakan suatu kesatuan strategi yang tidak dapat dipisahkan pelaksanaannya, dan harus dilaksanakan secara sinergis, terintegrasi dan berjalan serempak untuk mencegah munculnya regenerasi koruptor muda dan koruptor baru, sehingga timbul permasalahan bagaimanakah stragtegi pencegahan korupsi yang telah dilakukan oleh Pemerintah dalam rangka menuju Indonesia bersih dan kendala-kendala apakah yang dihadapi dalam rangka melaksanakan stragtegi pencegahan korupsi yang telah dilakukan oleh Pemerintah. Penelitian ini menggunakan metode pendekatan yuridis empiris dengan spesifikasi penelitian deskriptif analitis dan metode analisis bersifat diskriptif kualitatif dan analisis isi. Dari hasil penelitian dapat diketahui bahwa pemerintah telah memiliki strategi pencegahan dan pemberantasan korupsi namun demikian masih ditemukan kendala berupa masih banyak peraturan yang saling tumpang tindih, lemahnya pengawasan terhadap lembaga, aparatur dan unsur-unsur profesi yang berkait dengan penegakan hukum, belum maksimalnya perlindungan pelapor dan saksi.
\end{abstract}

Kata Kunci : korupsi, pencegahan tindak pidana korupsi, budaya hukum.

\section{Introduction}

In this era of reform, the government's determination to implement good and clean government often echo and welcome enthusiastically by all levels of Indonesian society, which has long longed for prosperity and fairness as mandated by the Preamble of 1945 Constitution. To achieve this, all forms of corruption must be eradicated, so the corruption is not rampant. ${ }^{1}$

This paper is a part of Grant Competency Scheme, No. Contract 2025/UN.23.14/PN/2015. Year 2015

Aprillani Arsyad, "Membudayakan Gerakan Anti Korupsi dalam Rangka Penanggulangan Korupsi di Indonesia”,
According to the assessment of Transparency International. In 2014 a score of CPI (Corruption Perception Index) Indonesia still ranks 109 of 175 countries measured, with a score of 34. This ranking clearly illustrates how the global views Indonesia. As for the ASEAN level, other countries rank much better. Singapore was ranked 7, Malaysia was ranked 51, Piliphina was ranked 91 and Thailand was ranked 38.

Jurnal Ilmu Hukum Universitas Jambi, Vol 5 No. 2 year 2014, Jambi: Law Faculty of Jambi University page 45. 
As the time goes by, realize or not, it turns out if only eradication policy is not enough, but it must be accompanied by a prevention policy that would be done comprehensively. In the context of mental revolution law which is supported by civil society is a part of the strengthening legal culture when view the law as a system. ${ }^{2}$ Thus the eradication and prevention of corruption must be implemented as synergy, integrated and run simultaneously to prevent the emergence of young and new corruptor.

Building the culture of anti-corruption law is a part of prevention. Legal culture is an atmosphere of social thought and social forces that determine how the law is used, avoided or misused, in the absence of cultural/legal culture, the legal system will be powerless. The legal culture elements include opinions, habits, ways of thinking, and ways to react in the leadership, in this case are the president, the officials of country, the officials of Country apparatus, as well as the law enforcement officers must be a role model for not violate the rule of law as corruption, so the legal culture will reduce the corruption. Considering the Indonesian culture who like to follow or imitate its leaders. Without the legal culture, legal system will be powerless. ${ }^{3}$

\section{Problems}

How does the corruption prevention strategy that has been done by the Government towards Indonesia Corruption-free?; What are the constraints that are faced in order to implement the corruption prevention strategy that has been done by the Government?

\section{Research Method}

This study uses empirical juridical approach, specifications analytical descriptive research. Qualitative descriptive data analysis and content analysis are used to analyze the concept of appropriate and integrated corruption prevention both the penal and non-penal in over- coming the corruption, thus this study use Research and Development/R\&D analysis method.

\section{Discussion}

\section{National Strategy for the Corruption Preven-} tion towards Indonesia Corruption-free

Government in 2012 through Presidential Decree No. 55 of 2012 launched the National Strategy (Stranas) Prevention and Eradication of Corruption (PPK) Long-term year 2012-2025 and Medium-term year 2012-2014. This regulation is a reference for every institution and ministry, including local governments in order to create an Indonesia Corruption-free. Then the regulation is sharpened in the leadership of President Joko Widodo, through Presidential Instruction No. 7 of 2015.

The vision of Stranas PPK is the realization of the nation's life that is corruption free with supported by the integrity cultural values, with a prevention and repression capacity supported by the integrity cultural values. The main aim of Stranas PPK is a form of reduction levels of corruption and make Indonesia people become a prosperous and corruption free. The indicators of accomplishment that are used i.e. the Improvement of Corruption Perception Index and the Improvement of Increased National Integrity System Index.

PPK National strategy (Stranas) becomes very important to be launched and implemented consider the bureaucracy quality ranking of Indonesia is not good. In the tables that are created by Kemenpan as shown below.

The condition as illustrated in the table above would be very unfavorable to the development of a good investment in Indonesia. The conditions are not good is happening in our country due to no cultural performances that are effective and efficient because organizations tend to be obese, overlapping legislation, incompetent HR.

\footnotetext{
Arfan Faiz Muhlizi, “ Revolusi Mental Untuk membentuk Budaya Hukum Anti Korupsi”, Jurnal Rechtsvinding, Vol 3 No. 3 December 2014, Jakarta : BPHN, page 453.

3 Diana Yusyanti, "Strategi Pemberantasan Korupsi Melalui Pendekatan Politik Hukum Penegakan Hukum dan Budaya
}

Hukum", E-Jurnal WIDYA Yustisia. Vol. 1 Nunber 2 February 2015. Jakarta: Law Faculty of Muhammadiyah University, page 95. 
Integrity in Indonesian Major Dictionary defined as the quality, nature, or the circumstances indicate a unified thus has the potential and ability to exude dignity, honesty. Such characters must be embedded in mind and behavior throughout the bureaucrats of the bureaucracy in Indonesia. National Integrity System Development uses a service approach that suits the characters and needs of the organization, so it is not directed to uniform strategies and activities, but to be open with the innovative and diverse initiatives, depend on the needs, capabilities, organizational characteristics.

Table 1 : The Ranking of Bureaucracy Quality Aspect in ASEAN ${ }^{4}$

\begin{tabular}{|l|c|}
\hline \multicolumn{2}{|c|}{ EoDB } \\
\hline \multicolumn{1}{|c|}{ CTRY } & RANK \\
\hline Singapore & 1 \\
\hline Malaysia & 6 \\
\hline Thailand & 18 \\
\hline Brunai & 59 \\
\hline Rusia & 92 \\
\hline China & 96 \\
\hline Vietnam & 99 \\
\hline Philipina & 108 \\
\hline Brasilia & 116 \\
\hline Indonesia & 120 \\
\hline India & 134 \\
\hline Khambodia & 137 \\
\hline Laos & 159 \\
\hline Myanmar & 182 \\
\hline
\end{tabular}

\begin{tabular}{|l|c|}
\hline \multicolumn{2}{|c|}{ GCR (INST.) } \\
2013-2014 \\
\hline \multicolumn{1}{|c|}{ CTRY } & RANK \\
\hline Singapore & 3 \\
\hline Brunai & 25 \\
\hline Malaysia & 29 \\
\hline China & 47 \\
\hline Laos & 63 \\
\hline Indonesia & 67 \\
\hline India & 72 \\
\hline Thailand & 78 \\
\hline Philipina & 79 \\
\hline Brasilia & 80 \\
\hline Khambodia & 91 \\
\hline Vietnam & 98 \\
\hline Rusia & 121 \\
\hline Myanmar & 141 \\
\hline
\end{tabular}

Note:

EoDB $=$ Ease of Doing Business (IFC, WB) (2014)

GCR (Inst.) = Global Competitiveness Report (Variabel Institution)

Police and the Attorney of Republic Indonesia as part of the law enforcement pillar have a strategic role in both prevention and enforcement, especially corruption. Therefore, building the integrity culture within these two institutions are very important. Without the integrity of law enforcement, Indonesia Corruption-free will never be real as expected.

Police agency launches Grand Police Strategy 2005-2025 which is divided into three (3) phases, namely Trust Building Phase (20052009), Partnership Phase (2010-2014) and Strive for Excellence Phase (2015-2025). The current stage of implementation can not be said to be perfect, however, there has been some improvement as expected.

Police have been implemented the reform and optimization of the rule of law through the implementation of the Reforms wave I with varying success that has been achieved, which is the assessment team of independent national bureaucratic reform states that the implementation of the transparency of the investigation task get a score of 3.88 with a good value. Besides, the results of Kompolnas research in law area of 10 Police in Indonesia, with the results of the law enforcement aspect of $59.3 \%$, which means in the enough category. However, there is no doubt that it is still found weakness and deficiency in law enforcement efforts from police so there is still complain from society to Itwasum Police, Divpropam Police, Wassidik Bureau Bareskrim Police, Divkum Police, the Ombudsman, Kompolnas, Commission III DPR RI, DPD RI, and the Judicial Mafia Task Force and NGOs.

General Attorney issued Circular Letter No. SE-025/A/JA/11/2013, which explains several steps Corruption Prevention Strategic and Strengthening Corruption Eradication in R.I. Attorney. Circular Letter provides three strategies to implement them, as described below:

\begin{tabular}{|l|l|}
\hline Strategy 1 & $\begin{array}{l}\text { Strengthening anti-corruption culture } \\
\text { through the effectiveness of anti-cor- } \\
\text { ruption education, in order to esta- } \\
\text { blish an anti-corruption awareness in } \\
\text { the form of refusal attorney's emplo- } \\
\text { yees towards corrupt behavior. }\end{array}$ \\
\hline Strategy 2 & $\begin{array}{l}\text { Effective corruption prevention thro- } \\
\text { ugh the com-prehensive synergy of } \\
\text { the management of state finances } \\
\text { and the improvement of public servi- } \\
\text { ces in R.I. Attorney to achieve good } \\
\text { governance and Corruption-free } \\
\text { (Good clean Government). }\end{array}$ \\
\hline Strategy 3 & $\begin{array}{l}\text { Strengthening the integrity and capa- } \\
\text { city of prosecutor in the discharge of } \\
\text { strict law enforcement objectively in } \\
\text { effecting the corruption eradicati-on. }\end{array}$ \\
\hline
\end{tabular}

Attorney institution lays out the strategy into action in the form of integrity increasing for prosecutor apparatus and giving reward \& pu- 
nishment. While the translation for society is the establishment of the Guard and the Government Security and Development (TP4P). Both TP4P and TP\$D at the region level have concerned task on the prevention of corruption. On one side the village development budget absorption can be maximized while in the other hand the decision makers in region obtain adequate legal assistance. TP4 function is becoming a concrete part of the prosecutor institution to perform the function of prevention. So the prosecutor institution is not only seen as the only party able to find fault but also able to educate people about how to use the budget according to legislation provisions.

Successful bureaucratic reforms will able to reduce and eventually eliminate any abuse of public authority, which will improve the qu-ality of service to society, improve the ability to formulate and implement the institute policies/ programs and cost and time efficiency. Thus the anticipative, proactive, and effective Indonesian bureaucracy be achieved. However, if it fails, then the reform of the bureaucracy will only lead to the inability of the bureaucracy to face the complexity which move exponentially in the $21^{\text {st }}$ century, reduce public confidence to government, and the threat of failure to achieve good governance, even obstruct the success of national development.

Process of bureaucratic reform accomplishment would take long time, until now the experience of bureaucratic reform that goes according to the step only owned by the Ministry of Finance. Rezising in the organizational structure and the golden shake hand for employees who do not pass the competency are some condition that occurs in Ministry of Finance. As for the other institutions are still at the early stages of value investment to the apparatus so that still more ceremonial.

Obstacles Faced in order to Carry Out Corruption Prevention Strategy that has been done by the Government.

5 Zudan Arif Fakrulloh, “ Akuntabilitas Kebijakan dan Pembudayaan Anti Korupsi”, Jurmal Perspketif, Vol XVI No.
Public service areas become the central point concern of corrupt behavior prevention policy as well as benchmarks for an institution/ department for successfully prevent corrupt behavior in each region that become their responsibilities. There are prominent things in a society which clean from corruption and became its trademark which are: first, Bureaucracy as public servants feel responsible for their service, afraid to charge unofficial and will receive an official incentive for behave honestly; second, The society consider the rules to be adhered so that the society behave in the regulatory framework; and third, Society do not need to pay unofficial incentives (commissions, kickbacks, bribes) because they know that without paying those, they will be protected for their rights to receive quality public services. ${ }^{5}$

Talking law as a system, the "mental revolution" as disclosed in the vision of President Joko Widodo is closely related to legal culture. The rise of corrupt behavior have to be inhibited by the growth of legal culture through a mental revolution planned by the president.

Mental reformation is a long work that is faced with many obstacles. Many governance systems are still not transparent, that become the important things that still have to be improved. Besides, encouraging society participation in the supervision function is quite important to be developed. Concrete examples of society participation that quite high in carried out supervision function to government is as do by Singapore citizen, it able to create the country clean from corruption.

Clean, effective, efficient, and transparent governance are indicators of the low level of corruption in bureaucracy area. Commonly, one of the main components of e-gov is a government information system application that able to provide online services via Internet. This application facilitates interaction between society members and public service providers without having to meet face to face which is ba-

2, April 2011, Surabaya: Wijaya Kusuma University, page 105. 
sically give a space for intrigue that leads to corruption. ${ }^{6}$

Obstacles faced by both Police Institution and Prosecutor Institution to carry out bureaucracy reformation are HR needs that can meet the expectations of society. The implementation of reward and punishment in the law enforcement institutions has been running, with the hope of both institutions can spearhead law enforcement authority.

Bureaucratic reformation in order to develop the national integrity system is a shared responsibility, build an anti-corruption culture should start from early ages, the success of anticorruption education affects the mindset of that generation. Recruitment for law enfor-cement and public servants should became concern. With the advent minimize corruption system is expected to elect a human resource personnel who can be trusted.

Obstacles such as there are many laws and regulations that still overlapped and out-dated should be a priority for immediate revision and harmonization thus able to eliminate opportunities for corruption and harmonious and adequate regulation are established for the prevention and eradication of corruption, creating compatibility between the provisions of the UNCAC by law applied in Indonesia. Public participation and religious organi-zations in order to prevent corrupt behavior has been carried out, on October 15, 2003 Nadhatul Ulama and Muhammadiyah as the largest Muslim organization in Indonesia have made a MoU to jointly implement prevention and eradication of corruption.

Andrew Haynes said that the new paradigm in tackling crime can be done by eliminating the passion and motivation of perpetra-tors to commit a crime, by prevents them from enjoying the result their crime. ${ }^{7}$ Besides, of course

6 Mugi Hartana, "Efektivitas Penerapan E-Government dalam Pencegahan Tipikor di Lingkungan Pemda", Jurnal Panggung Vol 1 No. 2, 2015. Yogyakarta: Perhimpunanan Mahasiswa Hukum Cab. Yogyakarta, page 69.

7 Halif, "Pencegahan dan Pemberantasan Tipikor melalui UU Pencucian Uang", Jurnal Anti Korupsi Vol 2 No. 2 2012, Jember : Pusat Kajian Anti Korupsi FH Universitas Jember, page 70 .

8 Lukman Hakim, “Model Integrasi Pendidikan Anti Korupsi Dalam Kurikulum Pendidikan Islam”, Jurnal PAI-Ta'lim accompanied strengthen the integrity of all levels of society, especially the younger generations through education that focuses on planting anti-corruption culture.

Formal education sector in Indonesia simplistically could play a role in meeting the needs of the prevention of corruption. The preventive measures indirectly can be done through two approaches: first, to make learners as a target; and second, empower learners to suppress environment order not permissive to corruption. ${ }^{8}$

Anticorruption learning must involve students actively in building meaningful knowledge. Active learning requires learning activities where students are given enough autonomy to control the direction of learning activities such as investigating, solving problems, learning in small groups, and so on. In other words, the anticorruption learning can use various ways or strategies, as long as the method or strategy involves students actively both physically and mentally. ${ }^{9}$

Media is an essential part in efforts to prevent corruption, since transparency create messages that are useful for the prevention, investigation or combating corruption. Freedom of information at least are able to: first, reduce corruption substantially in the various public institution; second, supervising the tendency of public officials who commit corruption; and third, minimizing the patterns of corruption carried out systematically through the institutionalization of the attitudes and behaviors into a corrupt organization culture. ${ }^{10}$

Optimization of prevention must be done by all sectors of activity, both for the state/government bodies and law enforcement bodies or community in the other hand, the prevention of which is carried out integratively and sustain-

Vol 10 No. 22, 2012, Jambi : Fak. Tarbiyah IAIN Sulthan Thaha Saifuddin, page 144 .

9 Maria Montessori, "Pendidikan Anti Korupsi sebagai Pendidikan Karakter di Sekolah", Jurnal Demokrasi, Vol 11 No. 1 2012, Padang: Fak. Ilmu Politik Univ. Negeri Padang, page 298.

10 Eko Harry Susanto, "Eksistensi Media dalam Pemberantasan Korupsi”, Jurnal Karya Ilmiah Dosen FIKOM, Vol. 1. No. 1, 2012, Jakarta: Fak. Ilmu Komunikasi Univ. Tarumanegara. 
ably will be able to reduce the rate of criminals regenerations and improve governance.

The role of Corruption Eradication Commission (KPK) carefully and sustainably designing techniques and ways of prevention to be implemented for all levels of society, as well as other law enforcement agencies are expected to improve the performance and governance of its human resources in order to be able to shield themselves from corrupt behavior.

\section{Closing \\ Conclusion}

National Strategy for the prevention of corruption in order to corruption-free Indonesia has been proposed by the Government. Police agencies and the Attorney as sharp edges of law enforcement has undertaken efforts to reform the bureaucracy thoroughly in order to meet the expectations of society. Prevention, prosecution and rewards become part of implementing such efforts. While the Attorney institute also seeks prevention and education community through the establishment of Tim TP4. However, so far it is only a form of ceremonial, one of them is declaration of action to reform the bureaucracy, the signing of integrity pact, the use of anticorruption symbols. Meanwhile, there is already some institution carrying out more forcefully like the Ministry of Finance; The result of implementation of corruption prevention programs not necessarily be felt in short term regarding various problems faced at each different institution. Supervising function in general is not running optimally, community participation to watch over the governance that is free from corruption have not received an adequate place.

\section{Suggestion}

Revising some overlaping legislative regulation should be implemented immediately, especially in regulation of corruption; Law enforcement are expected to educate the public and the government authorities in implementing good and correct government administration and financial.

\section{References}

Arif Fakrulloh, Zudan. “Akuntabilitas Kebi-jakan dan Pembudayaan Anti Korupsi”. Jurmal Prespketif, Vol XVI No. 2 April 2011. Surabaya: Wijaya Kusuma University;

Arsyad, Aprillani. “Membudayakan Gerakan Anti Korupsi Dalam Rangka Penanggulangan Korupsi di Indonesia". Jurnal Ilmu Hukum Universitas Jambi, Vol 5 No.2 Year 2014. Jambi : Law Faculty of Jambi University;

Faiz Muhlizi, Arfan. "Revolusi Mental untuk Membentuk Budaya Hukum Anti Korupsi". Jurnal Rechtsvinding. Vol 3 No. 3 December 2014. Jakarta : BPHN;

Hakim, Lukman. "Model Integrasi Pendidikan Anti Korupsi Dalam Kurikulum Pendidi-kan Islam". Jurnal PAI-Ta'lim Vol 10 No. 22, 2012. Jambi: Tarbiyah Faculty of IAIN Sulthan Thaha Saifuddin;

Halif. "Pencegahan dan Pemberantasan Tipi-kor melalui UU Pencucian Uang". Jurnal Anti Korupsi Vol 2 No. 2 Year 2012. Jember: Pusat Kajian Anti Korupsi Law Faculty of Jember University;

Hartana, Mugi. "Efektivitas Penerapan E-Government dalam Pencegahan Tipikor di Lingkungan Pemda", Jurnal Panggung Vol 1 No. 2, 2015. Yogyakarta: Perhimpunanan Mahasiswa Hukum Cab. Yogyakarta;

Kemenpan. Penguatan Tata Kelola Pemerintahan yang baik melalui Refrmasi Birokrasi;

Montessori, Maria. "Pendidikan Anti Korupsi sebagai Pendidikan Karakter di Sekolah". Jurnal Demokrasi Vol 11 No.1 Year 2012. Padang: Politics Faculty of Univ. Negeri Padang;

Susanto, Eko Harry. "Eksistensi Media dalam Pemberantasan Korupsi”. Jurnal Karya Ilmiah Dosen FIKOM. Vol.1. No.1 Year 2012. Jakarta: Communication Faculty of Tarumanegara University;

Syarief Nurdin, Encep. "Pembangunan Tatakelola Pemerintahan Yang Baik (Good Governance) dan Pemberantasan Korupsi. Jurnal Negarawan Sekneg RI. No. 18, 2010. Jakarta : Sekretariat Negara RI;

Yusyanti, Diana. "Strategi Pemberantasan Korupsi Melalui Pendekatan Politik Hukum Penegakan Hukum dan Budaya Hukum". EJurnal WIDYA Yustisia. Vol. 1 Number 2 February 2015. Jakarta: Law Faculty of Muhammadiyah University. 